\title{
The Association of Bovine Osteopontin (OPN) Gene with Milk Production Traits in Iranian Holstein Bulls
}

\author{
Abdolreza Salehi 1,*, khadijeh Nasiri 1, Mahdi Aminafshar 2, Mohammad Bagher Sayaadnejad 3, \\ Rohoallah Sobhani 1
}

1Department of Animal and Poultry Science, College of Aburaihan, University of Tehran, Tehran, Iran
2Department of Animal Science, Faculty of Agriculture and Natural Resourse, Science and Research Branch, Islamic Azad
University, Tehran, Iran
${ }^{3}$ Animal Breeding Centre of Iran, Karaj, Iran
${ }^{*}$ Corresponding Author: Abdolreza Salehi, Department of Animal and Poultry Science, College of Aburaihan, University of Tehran, Tehran, Iran. Tel: +98-
2136040907, Fax: +98-2136040907, E-mail: arsalehi@ut.ac.ir

Received: December 02, 2014; Revised: Febuary 13, 2015; Accepted: March 08, 2015

Background: The Osteopontin $(O P N)$ is a highly phosphorylated glycoprotein in numbers of bovine tissues and milk. OPN has been reported to be associated with milk production in cattle.

Objective: The genotype and allelic frequencies for $O P N$ and its association with milk production will be evaluated in Iranian Holstein Bulls.

Materials and Methods: Bulls DNA (100) was isolated. Oligo was used for primer design. Polymerase Chain Reaction was implemented to amplify a 826 bp fragment and the amplicon was digested by BsrI. Restricted Maximum likelihood (REML) method based on average information algorithm using ASRMEL programs (version 3.1) was employed to estimate the genetic parameters and variance of components. The association of OPN genotypes with milk production traits were analysed by the least square method as applied in the general linear model (GLM) procedure of SAS. Allele substitution effects were performed by regression analyses.

Results: Allele frequencies of $\mathrm{T}$ and $\mathrm{C}$ were $0.59 \pm 0.03$ and $0.41 \pm 0.03$, respectively. Genotype frequencies of TT, CT and CC were 34.69, 48.62, and 16.69, respectively. The chi-square test showed the deviation from Hardy-Weinberg equilibrium. Estimated heritability for milk yield, fat yield and its percent, protein yield and its percent were $0.28 \pm 0.0061$, $0.21 \pm 0.0064,0.22 \pm 0.0086,0.32 \pm 0.0065$ and $0.34 \pm 0.0096$ respectively. Allelic substitution effects and differences between genotypes were not significant for milk production traits.

Conclusions: This study suggested that the $\mathrm{C}$ allele frequency of $O P N$ was noticeable in Iranian proven bull Holstein population, but was not associated with milk production traits. However, before being practical for the breeding improvement of Iranian Holsteins a larger sample size is required.

Keywords: Association; Iranian Holstein bulls; Milk production traits; OPN gene; Polymorphism

\section{Background}

The results of meta-analysis suggested that many quantitative trait loci (QTL) have been mapped for economic important traits in dairy cattle (1). Whole genome scans have identified quantitative traits loci affecting milk production traits on BTA6 close to $O P N$ loci $(2,3,4,5)$. Targeted gene identification, controlling economically important traits seems a way forward for future breeding programs. UTMP, $A B C G 2$, FGF2, PPARGC1A, DGAT1, STAT1 and OPN genes have strong effects on milk production and health traits in cattle $(6,7)$. A point mutation in the DGATl gene, which is responsible for nearly $43 \%$ of the genetic variation of fat percentage was identified (8). Khatib et al. (2007b) investigated the association of $O P N$ and PPARGC1A genes with milk production traits in the Holstein cattle populations. It has shown that in the Holstein population of, allele $\mathrm{C} O P N$ is associated with milk production traits (1). $O P N$ and $A B C G 2$ are genes (among the six in the $420-\mathrm{Kb}$ region) that are differentially expressed between different stages of lactation in the bovine mammary gland (9). In Cooperative Dairy DNA repository a single nucleotide polymorphism (SNP) reported in intron $4(\mathrm{C} / \mathrm{T})$ and has shown that allele $\mathrm{C} O P N$ gene is associated with milk production traits in dairy cattle (10). Tantia et al. 
(2008) investigated 9T/10T variation in the upstream region of $O P N$ in buffalo. Earlier, it was reported that $O P N$ is associated with milk in various livestock species. However, in this study no significant association was noted (11). Schnabel et al. (2005) reported a significant association between $O P N$ and protein percentage (12). They indicated that the $\mathrm{T}_{\mathrm{n}}$ motif in $O P N$ 3907, bears an osteopontin regulator element at further up to the gene promoter. The motif is moderately conserved among mammals (12). Osteopontin gene $(O P N)$ and PPARGC1A are located in the middle of chromosome 6 about $6 \mathrm{Mb}$ apart, which is approximately $12 \mathrm{cM}(6)$ and encodes osteopontin, the prime candidate among the six genes in the $420 \mathrm{~Kb}$ region (9). Osteopontin is a highly phosphorylated glycoprotein and is expressed in several tissues (13). The protein is found in urine (14), bile (13), milk (15), seminal plasma of Holstein bulls (16) and has been detected in bull accessory sex gland, seminal vesicle and ampullary fluids (16). Moreover, $O P N$ is highly expressed in bone, macrophages, endothelial, smooth muscle and epithelial cells (13). $O P N$ is involved in diverse biological, physiological and pathological processes including recruiting and stimulating macrophages in response to infection (13), interactions with ions (13), inflammation (17), biomineralization, leukocyte recruitment and cell survival (17). Cow milk was reported to have $8 \mathrm{mg} . \mathrm{L}^{-1} O P N$ (18). Both protein levels and mRNA of $O P N$ were highly expressed throughout the entire lactation (19).

\section{Objectives}

The importance of osteopontin in milk and its association with milk production traits, reported in earlier studies, prompted us to investigate polymorphism of $O P N$ in the Iranian Holstein bulls.

\section{Materials and Methods}

\subsection{DNA Samples}

A total of 100 Semen samples from progeny tested Iranian Holstein bull's were collected from animal breeding center in Karaj, Alborze province.

Genomic DNA was extracted from $200 \mu \mathrm{L}$ of semen using High Pure PCR Template Preparation Kit (Roche Company kit, CAD No=11796828001) along 7 $\mu \mathrm{L}$ Di Thiothreitol (DTT) and modified salting-out method. The DNA concentrations were measured via spectrophotometer (PicoDrop, England).

\subsection{DNA Amplification with PCR-RFLP}

The primers were designed with Oligo (version 7,
2011) based on available bovine genomic sequences (GenBank accession numbers: ID A878328) (20). Primer sequences were as follows: forward $5^{\prime}$-CTGAGGAAACTGATGACAAC- $3^{\prime}$ and reverse: $5^{\prime}$ GCTTTCATTGGACTTACTTGG-3'. The amplicon was $826 \mathrm{bp}$ in length that covered some part of exon 5, intron 5 and portion of intron 6 of the bovine $O P N$. The amplification reactions were performed in a total volume of $20 \mu \mathrm{L}$ using of Hot Start Taq plus PCR Master Mix (Qiagen Company kit, Tehran, Iran, CAD $\mathrm{No}=28104)$. Each PCR reaction had 50 ng of genomic DNA, $1 \mu \mathrm{L}$ of each primer $(10 \mathrm{pM}), 10 \mu \mathrm{L}$ of PCR kit $(10 \times), 2 \mu \mathrm{L}$ CoraLoad $(10 \times)$ in 35 cycles (initial denaturation: 95 for $5 \mathrm{~min}$; denaturation: 95 for $1 \mathrm{~min}$; annealing: 51.3 for $1 \mathrm{~min}$; extention: 72 for $1 \mathrm{~min}$ ) followed by a final extention at 72 , for $5 \mathrm{~min}$. The PCR products were digested with $B s r I$ ( $B s e \mathrm{NI})$ enzyme that distinguishes alleles $\mathrm{C}$ and $\mathrm{T}$. A single digestion reaction was consisted of $7 \mu \mathrm{L}$ of PCR product, $0.7 \mu \mathrm{L}$ of $B s r I$ enzyme (Fermentase, South Koria, Country), $2 \mu \mathrm{L}$ buffer $10 \times$ and $20.3 \mu \mathrm{L}$ nuclease free water. The final reaction volume of $30 \mu \mathrm{L}$ was incubated at 65 for $16 \mathrm{~h}$. The digestion products was subjected to $2 \%$ polyacrylamide gel electrophoresis (PAGE).

\subsection{Statistical Analysis}

The genotypic and allelic frequencies of $O P N$ variants were estimated using Pop Gene 32 software, version 1.31 (21). The Hardy-Weinberg equilibrium in the populations was tested. First lactation of Iranian Holstein was collected between 1993-2008 at the Animal Breeding center of Iran. The data were edited using from visual Foxpro and Excel softwares. The records of 305 days and twice milking per day was applied. The records of cows with the age at first calving between 18 to 38 months and lactation days more than 90 days were considered. Also animals without records were removed.

In order to identify factors affecting trait changes and to drive an optimum model before applying the final model to the data, preliminary analysis was performed. This was achieved by using of General Linear Model (GLM) procedure in SAS software (SAS Institute version 9.2, USA).

Genetic parameters and variance components were estimated by Restricted Maximum Likelihood (REML) based on average information algorithm using the ASRMEL programs, version 3.1 (22). The applied model for traits was as fallow in equation (1):

$$
\mathrm{Y}_{\mathrm{ij}}=\mu+\operatorname{HYS}_{\mathrm{j}}+\operatorname{Age}_{\mathrm{i}}+\mathrm{A}_{\mathrm{i}}+\mathrm{e}_{\mathrm{ij}}
$$


$\mathrm{Y}_{\mathrm{ij}}$ represent milk related traits, $(\mu)$ average population, $\left(\mathrm{A}_{\mathrm{i}}\right)$ animal effect as a random effect, $\left(\mathrm{Age}_{\mathrm{i}}\right)$ age of first calving as covariate factor, $\left(\mathrm{HYS}_{\mathrm{j}}\right)$ fixed effect of herd-year-season at calving and $\left(e_{\mathrm{ij}}\right)$ random residual effect.

Variance and covariance components were estimated and breeding value was predicted by using ASRMEL software (version 3.1) that it's based on average information algorithm.

The least square method of GLM procedure of SAS was applied to test the association of $O P N$ genotypes with milk production traits. The linear model was used as follow in equation (2):

$\mathrm{Y}_{\mathrm{ij}}=\mu+\mathrm{G}_{\mathrm{i}}+\mathrm{e}_{\mathrm{ij}}$

$\mathrm{Y}_{\mathrm{ij}}$ is the breeding value for milk related traits; $\mu$; least square means of the traits, $\mathrm{G}_{\mathrm{j}}$; effect of the $\mathrm{j}^{\text {th }}$ genotype $(\mathrm{j}=1,2,3)$ in $\mathrm{i}^{\text {th }}$ animal and $e$; the random residual effect.

Regression analyses were performed in which breeding value (BV) for milk yield, fat and protein yield and fat and protein percent were the dependent variables, and the genotype was the independent variable. The effect of allele substitution was determined by coding genotypes as TT (0), CT (1), and CC (2) to represent the number of $\mathrm{C}$ alleles present for the $O P N$ polymorphism. The average effect of allele substitution is known as regression coefficient $(\alpha)$, which is estimated as follows in equation (3):

$\mathrm{Y}_{\mathrm{i}}=\mu+\beta_{1} \mathrm{x}_{1 \mathrm{i}}+\Sigma \beta_{2 \mathrm{r}} \mathrm{x}_{2 \mathrm{ir}}+\mathrm{e}_{\mathrm{i}}$

$Y_{i}$ is the breeding value of ${ }_{i}$ th bull for related traits, $\mu$ is population mean, $\beta_{1}$ is regression coefficient of the breeding values on the corresponding value of their sire, $\mathrm{x}_{1 \mathrm{i}}$ is sire breeding value for corresponding trait of the $i^{\text {th }}$ bull, $\beta_{2 r}$ is regression coefficient of the bull breeding values for trait on the number of copies of the $\mathrm{r}^{\text {th }} O P N$ alleles, $\mathrm{x}_{2 \text { ir }}$ is the number of $\mathrm{C}$ alleles $(0,1,2)$ for the rth allele for ith bull and $e_{i}$ is the residual random effect.

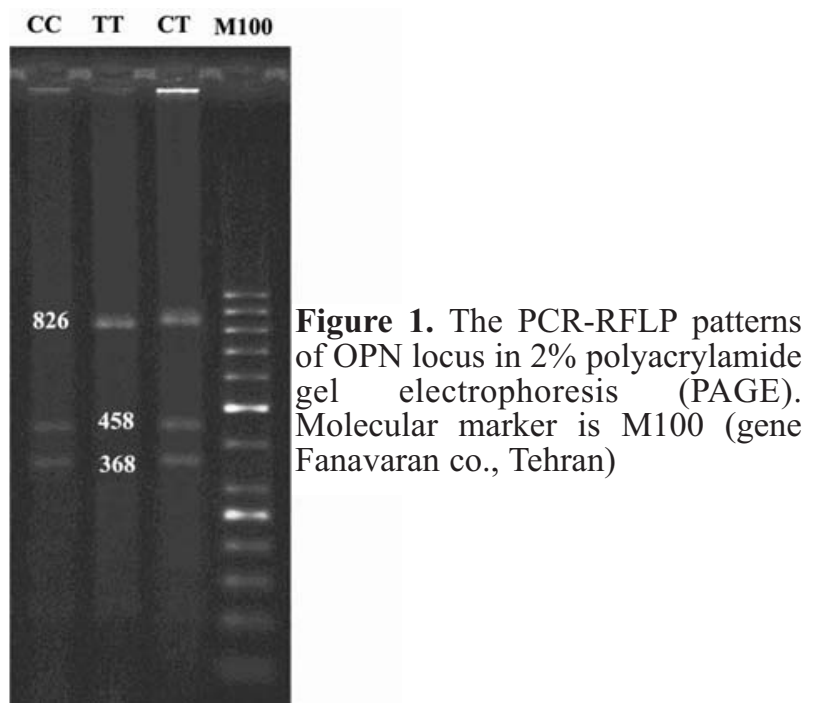

\section{Results}

PCR amplified a 826-bp fragment from a part of exon5, intron 5 and a part of exon 6 of $O P N$. Two alleles were found with $B s r I$ restriction enzyme. T allele had the fragment size of a $826 \mathrm{bp}$ (uncut) and $\mathrm{C}$ alleles had fragments of 368 , and 458 bp (Figure 1).

$O P N$ allelic and genotypic frequencies and chi-square $\left(x^{2}\right)$ value are summarized in Table 1. Allelic frequencies for $\mathrm{T}$ and $\mathrm{C}$ were $0.59 \pm 0.03$ and $0.41 \pm 0.03$, respectively. Genotype frequencies of TT, CT and CC were 34.69 , 48.62 , and 16.69 , respectively. The chi-square test $\left(x^{2}\right)$ showed deviation from Hardy-Weinberg equilibrium in the studied population.

Statistical description of data for milk production traits is shown in Table 2. Information regarding to the pedigree file is presented in Table 3. Variance components and genetic parameters estimated for production traits in Iranian Holstein dairy cattle are given in Table 4. This study did not indicate a significant association between the mutation in 10043 base of $O P N$ and milk production traits. Square means of the three $O P N$ genotypes are given in Table 5. No significant differences in production traits were found between differ-

Table 1. Genotypic and allelic frequencies with standard errors of single nucleotide polymorphism of bovine OPN genes in Iranian Holstein bulls

\begin{tabular}{|c|c|c|c|c|c|}
\hline \multirow[b]{2}{*}{ TT } & \multicolumn{2}{|c|}{ Genotypic frequency } & \multicolumn{2}{|c|}{ Allele frequency } & \multirow{2}{*}{$\begin{array}{c}\mathbf{x}^{2} \mathbf{p}<0.05 \\
4.82\end{array}$} \\
\hline & CT & $\mathrm{CC}$ & $\mathrm{T}$ & $\mathrm{C}$ & \\
\hline 34.69 & 48.62 & 16.69 & $0.59 \pm 0.03$ & $0.41 \pm 0.03$ & \\
\hline
\end{tabular}


Table 2. Statistical description for milk production traits

\begin{tabular}{lcccccc}
\hline Traits & $\mathbf{N}$ & Means & Minimum & Maximum & $\begin{array}{c}\text { Coefficient } \\
\text { of variation }\end{array}$ & $\begin{array}{c}\text { Standard } \\
\text { deviation }\end{array}$ \\
\hline Milk yield $(\mathrm{kg})$ & 239019 & 6786.30 & 2074.68 & 11312.18 & 22.08 & 1498.5 \\
Fat yield $(\mathrm{kg})$ & 216415 & 214.780 & 47.9 & 545.3 & 25.25 & 54.25 \\
Fat percent $(\%)$ & 216208 & 3.2 & 1.66 & 6.06 & 15.8 & 0.5 \\
Protein yield $(\mathrm{kg})$ & 116989 & 222.933 & 50.83 & 435.82 & 18.71 & 41.71 \\
Protein percent $(\%)$ & 116968 & 3.1 & 1.52 & 5.3 & 8.68 & 0.26 \\
\hline
\end{tabular}

Table 3. Summary of pedigree file for milk production traits in Iranian Holstein bulls from national breeding scheme

\begin{tabular}{lcccccc}
\hline $\begin{array}{l}\text { No. animals in } \\
\text { pedigree file }\end{array}$ & $\begin{array}{c}\text { No. } \\
\text { founders }\end{array}$ & $\begin{array}{c}\text { No. individuals } \\
\text { with both known } \\
\text { parent }\end{array}$ & $\begin{array}{c}\text { No. } \\
\text { non-founder }\end{array}$ & $\begin{array}{c}\text { No. } \\
\text { sire }\end{array}$ & $\begin{array}{c}\text { No. } \\
\text { dam }\end{array}$ & $\begin{array}{c}\text { No. } \\
\text { of inbreed } \\
\text { inbreeding } \\
\text { coefficients }\end{array}$ \\
\hline 362044 & 37963 & 301015 & 324081 & 7157 & 208972 & 204513 \\
\hline
\end{tabular}

Table 4. Heritability, genetic variance, residual variance, phenotypic variance and their standard errors in Iranian Holstein bulls from national animal breeding scheme

\begin{tabular}{lcccc}
\hline Traits & heritability \pm SE & Genetic Variance & Residual Variance & Phenotypic Variance \\
\hline Milk yield & $0.28 \pm 0.0061$ & 349724 & 905130 & 124854 \\
Fat yield & $0.21 \pm 0.0064$ & 268.752 & 964.329 & 1233.081 \\
Fat percent & $0.22 \pm 0.0086$ & 232.237 & 818.165 & 1050.402 \\
Protein yield & $0.32 \pm 0.0065$ & 0.0494093 & 0.103380 & 0.152789 \\
Protein percent & $0.34 \pm 0.0096$ & 0.0133010 & 0.0253976 & 0.038699 \\
\hline
\end{tabular}

Table 5. Least Square means of breeding values for milk production, fat and protein yield, and fat and protein percent in Iranian Holstein bulls with three $O P N$ genotypes

\begin{tabular}{|c|c|c|c|}
\hline \multirow[t]{2}{*}{ Traits } & \multicolumn{3}{|c|}{ OPN genotypes } \\
\hline & $\begin{array}{c}\text { TT } \\
(n=40)\end{array}$ & $\begin{array}{c}\text { CT } \\
(n=38)\end{array}$ & $\begin{array}{c}\text { CC } \\
(n=22)\end{array}$ \\
\hline Milk yield $(\mathrm{kg})$ & 173.95 & 119.17 & 157.5 \\
\hline Fat yield (kg) & 4.2 & 3.56 & 6.02 \\
\hline Fat percent (\%) & -0.067 & -0.035 & -0.035 \\
\hline Protein yield (kg) & 33.28 & 31.95 & 34.04 \\
\hline Protein percent $(\%)$ & -0.0048 & -0.03 & -0.04 \\
\hline
\end{tabular}

ent genotypes. However, CC genotype had higher fat yield $\left(6.02_{\mathrm{kg}}\right)$, protein yield $\left(34.04_{\mathrm{kg}}\right)$, fat and protein percent $(-0.035,-0.04)$ but lower milk yield than TT genotype $\left(157.5_{\mathrm{kg}}\right.$ VS $\left.173.95_{\mathrm{kg}}\right)$ The effects of substituting $\mathrm{T}$ with $\mathrm{C}$ allele are given in Table 6 . The average effect of replacing $\mathrm{T}$ with $\mathrm{C}$ for $B s r \mathrm{I}$ were amounted to be $-13.5 \mathrm{~kg}$ for milk, $0.73 \mathrm{~kg}$ for fat yield and $0.18 \mathrm{~kg}$ for protein yield and 0.017 , and 0.005 for fat and protein percent, respectively. In Iranian proven bulls population, the $\mathrm{C}$ allele was associated with an increase in milk protein percentage and milk fat percentage, which earlier was confirmed by Leonard et al. (2005).

\section{Discussion}

Whole genome scans have identified QTL affecting 
Table 6. Estimates $( \pm \mathrm{SE})$ of average allele substitution effects (allele C) on milk production traits in Iranian Holstein bulls

\begin{tabular}{lccc}
\hline Traits & $\alpha$ & SE & $\boldsymbol{P}$ values \\
\hline Milk yield $(\mathrm{kg})$ & -13.45 & 73.4 & 0.85 \\
Fat yield $(\mathrm{kg})$ & 0.73 & 2.14 & 0.73 \\
Fat percent $(\%)$ & 0.017 & 0.016 & 0.3 \\
Protein yield $(\mathrm{kg})$ & 0.18 & 1.95 & 0.92 \\
Protein percent $(\%)$ & 0.005 & 0.009 & 0.55 \\
\hline
\end{tabular}

milk production traits in dairy cattle on chromosome 6 close to $O P N$ loci $(2,3,4,5)$. Osteopontin $(O P N)$ is located in the middle of chromosome 6 . The objective of this study was to investigate the association of OPN variants $(\mathrm{C} / \mathrm{T}$ polymorphism) with milk production traits in Iranian Holstein bull population. The $\mathrm{C}$ allele frequency obtained in this study was in agreement with results reported by Leonard et al. (2005), Khatib et al. (2007). Leonard et al. (2005) reported frequencies of C and $\mathrm{T}$ alleles for $O P N$ gene in the Holstein population of Wisconsin University, 0.49 and 0.51 , respectively and seemed to be evenly distributed in the population. Khatib et al. (2007b) revealed frequencies of CC, CT and TT genotypes in the Wisconsin University, 0.23, 0.51 and 0.26 , respectively. It was close to HardyWeinberg equillibrium (6). Pasandideh et al. (2011) showed frequencies of CC, CT and TT genotypes in Tehran and Esfahan provinces, 19, 57 and 24 percent, respectively and were found to be significantly deviating from the Hardy-Winberge equilibrium (23). Oztabak et al. (2008) reported allele frequencies of $\mathrm{T}$ and $\mathrm{C}$ for $O P N$ in East Anatolian and South Anatolian Red cattle, 0.74 and 0.26 , and 0.84 and 0.16 for East Anatolian, respectively. Samples from two cattle breeds were found to be in Hardy-Weinberg equilibrium. In both breeds, frequency of $\mathrm{T}$ allele was found higher than $\mathrm{C}$ alleles. They showed that the frequency of allele $\mathrm{C}$ in South Anatolian Red was higher than that was found in East Anatolian Red cattle (24). Allele C was associated with milk protein percentage (12). Cohen et al. (2004) introduced $O P N$ as a candidate gene affecting milk protein percentage (25).

Several genome scans have identified QTLs affecting milk production on BTA 6 close to $O P N$ location in Boss taurus $(2,3,4,5)$.

Leonard et al. (2005) reported that $\mathrm{C}$ allele was associated with increasing milk protein percentage $(\mathrm{P}$ $=0.0255)$ and fat percentage $(P=0.0480)$ in Cooperative Dairy DNA Repository population
(CDDR). OPN variants did not show significant effects on milk, fat or protein yield or somatic cell score (SCS). Also, they showed that effects of allele C were in the same direction (negative for milk yield and positive for milk protein percentage) in Wisconsin University's population as for the CDDR population, although these estimates did not reach a level of statistical significance (10).

Khatib et al. (2007b) reported single nucleotide polymorphism of the $O P N$ gene in the University of Wisconsin resource population for which additive effects were significant for milk fat percentage $(P<$ $0.0001)$, milk protein percentage $(P<0.0001)$ and fat yield $(P=0.014)$ while, dominance effects were not significant for any of the examined traits (26).

Researches revealed that $O P N$ in the middle of BTA6, showed the highest linkage disequilibrium effects on protein percentage.

In the studied population, estimation effects of allele $\mathrm{C}$ were in the same direction with results reported by Leonard et al. (2005) in UW population and in contrast with results reported by Leonard et al. (2005) in CDDR population. This could be due to the small number of animals that was accessible for genotyping as the whole Iranian proven bull population and also different genetic background of animals.

The results obtained from this study showed that the $\mathrm{C}$ allele of $O P N$ was not significantly associated with milk production traits in Iranian proven bulls population.

This study suggested that the $\mathrm{C}$ allele frequency of $O P N$ was noticeable in Iranian proven bull Holstein population, but was not associated with milk production traits. However, before being practical for the breeding improvement of Iranian Holsteins a larger sample size is required.

\section{Acknowledgements}

This study was conducted at the Research Station of Aburaihan Campus, University of Tehran. Data and semen samples of Iranian Holstein bulls were provided through the Animal Breeding Center of Iran. We gratefully thank involved people in the study.

\section{References}

1. Khatib H, Zaitoun I, Wiebelhaus-Finger J, Chang YM, Rosa GJM. The Association of Bovine PPARGC1A and OPN Genes with Milk Composition in Two Independent Holstein Cattle Populations. J Dairy Sci. 2007b;90:2966-2970. DOI: 10.1186/1297-9686-36-2-163

2. Zhang Q, Boichard D, Hoeschele I, Ernst C, Eggen A, Murkve B, Pfister-Genskow M, Witte LA, Grignola FE, Uimari P, Thaller G, and Bishop MD. Mapping QTL for milk production 
and health of dairy cattle in a large outbred pedigree. Genetics. 1998;149:1959-1973.

3. Nadesalingam J, Plante Y, Gibson J. Detection of QTL for milk production on chromosomes 1 and 6 of Holstein cattle. Mamm Genome. 2001;12:27-31.

4. Ron M, Kliger D, Feldmesser E, Seroussi E, Ezra E, Weller JI. Multiple quantitative trait locus analysis of bovine chromosome 6 in the Israeli Holstein population by a daughter design. Genetics 2001;159:727-735.

5. Olsen HG, Lien S, Svendsen M, Nilsen H, Roseth A, Opsal MA, Meuwissen THE. Fine mapping of milk production QTL on BTA6 by combined linkage and linkage disequilibrium analysis. J Dairy Sci. 2004;87(3):690-698. DOI: 10.3168/jds. S0022-0302(04)73212-9

6. Khatkar MS, Thomson PC, Tammen I, Raadsma HW. Quantitative trait loci mapping in dairy cattle: Review and meta-analysis. Genet Sel Evol. 2004;36:163-190. DOI: 10.3168/jds.2006-722

7. Moosavizadeh M, Salehi A, Aminafshar M, Sayyadnejad MB, Nazemshirazi MH. Novel SNPs of the ABCG2 gene and their associations with milk production traits in Iranian Holstein bulls. J Agr Sci Tech. 2013;15:1145-1151.

8. Grisart B, Coppieters W, Farnir F, Karim L, Ford C, Berzi P, Cambisano N, Mni M, Reid S, Simon P, Spelman R, Georges M, Snell R. Positional candidate cloning of a QTL in dairy cattle: identification of a missense mutation in the bovine DGAT1 gene with major effect on milk yield and composition. Genome Res. 2002;12:222-231. DOI: 10.1101/gr.224202

9. Cohen-Zinder M, Seroussi E, Larkin DM, Loor JJ, verts-van der Wind AE, Shari M, Lewin HA, Weller JI, Ron M. Identification of a missense mutation in the bovine ABCG2 gene with a major effect on the QTL on a chromosome 6 affecting milk yield and composition in Holstein cattle. Genome Res. 2005;15:936-944.

10. Leonard S, Khatib H, Schutzkus V, Chang YM, Maltecca C. Effects of the Osteopontin gene variants on milk production traits in dairy cattle. J Dairy Sci. 2005;88:4083-4086. DOI: 10.3168/jds.S0022-0302(05)73092-7

11. Tantia MS, Mishra B, Bharani kumar ST, Mishra BP, Katraria RS, Mukesh M, Vijh RK. Characterization of Osteopontin gene of Bubalus bubalis. Animal. 2008;2:987-990. DOI: http://dx.doi.org/10.1017/S0022029900027503

12. Schnabel RD, Kim JJ, Ashwell MS, Sonstegard TS, Van Tassell CP, Connor EE, Taylor JF. Fine-mapping milk production quantitative trait loci on BTA6: Analysis of the bovine osteopontin gene. Proceeding of the National of Sciences of the United States of America. 2005;102:6896-6901.

13. Denhardt DT, Guo X. Osteopontin: a protein with diverse functions. FASEB J. 1993; 7:1475-1482.

14. Shiraga H, Clayman MD, Neilson EG, Hoyer JR. Affinity purification of urinary crystal growth inhibitor (CGI). Kidney Int. 1989;35:363. DOI: 10.1073/pnas.0502398102

15. Sorensen ES, Petersen TE. Purification and characterization of three proteins isolated from the proteose peptone fraction of bovine milk. J Dairy Res. 1993;60:189-197.

16. Cancel AM, Chapman DA, Killian GJ. Osteopontin localization in the Holstein bull reproductive tract. Biol Reprod. 1999;60:454-460. DOI: 10.1095/biolreprod60.2.454
17. Oregan AW, Chupp GL, Lowry JA, Goetschkes M, Mulligan $\mathrm{N}$, Berman JS. Osteopontin is associated with T cells in sarcoid granulomas and has $\mathrm{T}$ cell adhesive and cytokine-like properties in vitro. J Immunol. 1999;162:10224-10231. DOI: 10.3168/jds.S0022-0302(04)73212-9

18. Bayless KJ, Davis GE, Meininger GA. Solation and biological properties of osteopontin from bovine milk. Protein Expr Purif. 1997;9:309-314. DOI: 10.1006/prep.1996.0699

19. Nagatomo $\mathrm{T}$, Ohga $\mathrm{S}$, Takada H, Nomura S, Hikino A, Imura M, Ohshima K and Hara T. Microarray analysis of human milk cells: Persistent high expression of osteopontin during the lactation period. Clin Exp Immunol. 2004;138:47-53. DOI: $10.1007 / \mathrm{s} 003350010232$

20. Rychlik W. OLIGO primer analysis software version 7. Molecular Biology Insights Isc, Cascade, USA, Edithions. 2011.

21. Yeh FC, Yang Rong-cai, Boyle T. POPGENE version 1.31. University of Alberta and Center for International Forestry Research. 1999. DOI: http://dx.doi.org/10.1017/S175173 1108002073

22. Gilmour AR, Gogel BJ, Cullis BR, Thompson R. ASREML software version 3.1., NSW Department of Primary Industries. 2012.

23. Pasandideh M, Mohammadabadi M, Tarang A, Esmailizade Koshkoiyeh A, Sayghalani R, Ansari Mehyari S, Pasandideh $\mathrm{R}$ Analysis of bovine PPARGC1A and OPN genes polymorphism in Holstein dairy cows in Tehran and Esfahan provinces. Iran J Anim Sci. 2011;42:199-205. DOI: 10.1080/09064700802357771

24. Oztak K, Un C, Tesfaye D, Akis I, Mengi A. Genetic polymorphism of osteopontin (OPN), Prolactin (PRL) and Piturity specific transcript factor1 (PIT1) in south antolian and east antolian red cattle. Anim Sci. 2008;58:109-112.

25. Cohen M, Seroussi E, Band MR, Lewin HA, Drackley JK, Larkin DM, verts-van der Wind A.E, Heon-Lee J, Loor JJ, M Shani. SPP1 is a candidate gene for the QTL affecting milk protein concentration on BTA6 in Israeli Holstein. 29th Int. Soc Anim Gen. ISAG, F015, Tokyo, Japan. 2004.

26. Khatib H, Schutzkus V, Chang YM, Rosa GJM. Pattern of expression of the uterine milk. Protein gene and its association with productive life in dairy cattle. J Dairy Scie. 2007a;90:2427-2433. DOI: $10.3168 /$ jds.2006-812 